Florida International University FIU Digital Commons

$3-24-2010$

\title{
Freedom of religion : a case study of the Church of Lukumí Babalú Ayé v. City of Hialeah
}

David Maurice Aelion

Florida International University

DOI: $10.25148 /$ etd.FI13101534

Follow this and additional works at: https://digitalcommons.fiu.edu/etd

Part of the Religion Commons

\section{Recommended Citation}

Aelion, David Maurice, "Freedom of religion : a case study of the Church of Lukumí Babalú Ayé v. City of Hialeah" (2010). FIU Electronic Theses and Dissertations. 1105.

https://digitalcommons.fiu.edu/etd/1105

This work is brought to you for free and open access by the University Graduate School at FIU Digital Commons. It has been accepted for inclusion in FIU Electronic Theses and Dissertations by an authorized administrator of FIU Digital Commons. For more information, please contact dcc@fiu.edu. 


\section{FLORIDA INTERNATIONAL UNIVERSITY}

Miami, Florida

FREEDOM OF RELIGION: A CASE STUDY OF THE CHURCH OF LUKUMÍ BABALÚ AYÉ V. CITY OF HIALEAH

A thesis submitted in partial fulfillment of the requirements for the degree of MASTER OF ARTS in

RELIGIOUS STUDIES

by

David Maurice Aelion

2010 
To: Dean Kenneth Furton

College of Arts and Sciences

This thesis, written by David Maurice Aelion, and entitled Freedom of Religion: A Case Study of the Church of Lukumí Babalú Ayé v. City of Hialeah, having been approved in respect to style and intellectual content, is referred to you for judgment.

We have read this thesis and recommend that it be approved.

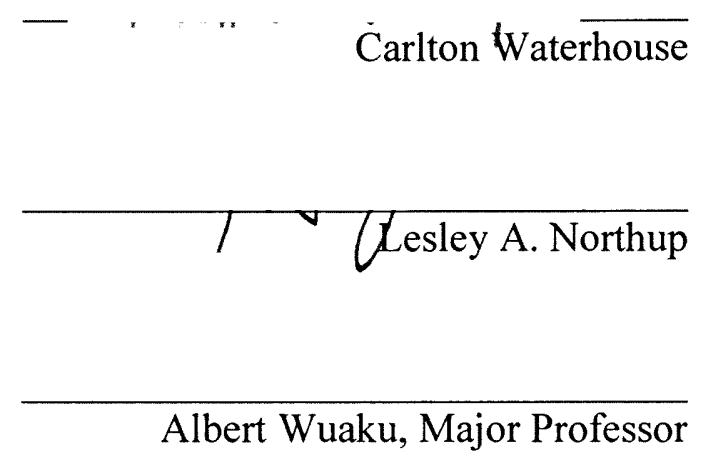

Date of Defense: March 24, 2010

The thesis of David Maurice Aelion is approved.

Dean Kenneth Furton College of Arts and Sciences

Interim Dean Kevin O'Shea University Graduate School

Florida International University, 2010 


\section{DEDICATION}

I dedicate this thesis to my mother Claudette Aelion for inspiring me to always create my own educated worldview; to my uncle Dr. Malka for his persistence in seeking education about all religions and helping me possess an educated basis under which not to judge any faith; and to my father Maurice Aelion who led by example. I dedicate this work to my staff, Barbie Domino, Shirley Gozon, Paula Salt, Edward S. Weinstein and Luz Weinberg, who have been incredibly patient throughout this process and the many hours that it has taken me away from the office. Without their patience, support and understanding, the completion of this exciting project would not have been possible. 


\section{ACKNOWLEDGMENTS}

I wish to thank the members of my committee: Professors Carlton Waterhouse and Lesley Northup, with a special appreciation to my Major Professor, Albert Wuaku for all their continuous direction, redirection and guidance in the preparation of this thesis. This entire, lengthy process would have also not been possible without Ernesto Pichardo, whose tireless efforts on behalf of the Lukumí Tradition over the past few decades have been invaluable to the faith. You have all made this extensive and challenging process an enjoyable, rewarding, exciting and educational journey. 


\title{
ABSTRACT OF THE THESIS
}

\section{FREEDOM OF RELIGION: A CASE STUDY OF THE CHURCH OF LUKUMÍ}

\author{
BABALÚ AYÉ V. CITY OF HIALEAH \\ by \\ David Maurice Aelion \\ Florida International University, 2010 \\ Miami, Florida \\ Professor Albert Wuaku, Major Professor
}

This thesis attempted to explain society's worldview of Santería and its practice of animal sacrifice, and the breakdown between the federal and local government after a 1993 Supreme Court ruling affirming their right to engage in this sacred ritual. Santería practitioners are harassed and prosecuted for exercising their right to practice animal sacrifice. The research was intended to present the cosmology of the Lukumi tradition, the intellectual framework explored, a review of Freedom of Religion and the case of Lukumi v. Hialeah, and finally the media's role in shaping the worldview of Santería that have perpetuated this breakdown. The thesis consisted of 87 research items, a community survey, interviews, a Santería divination, and review of case law, books, newspaper and online journals. These findings demonstrated that freedom of religion is not so free in the U.S., and exists only to the extent the media and municipal laws choose to allow. 


\section{TABLE OF CONTENTS}

CHAPTER

PAGE

I. INTRODUCTION 1

II. INTELLECTUAL FRAMEWORK 5

III. LUKUMÍ COSMOLOGY AND ANIMAL SACRIFICE 12

IV. THE CHURCH OF LUKUMÍ BABALÚ AYÉ 17

V. CHURCH OF LUKUMÍ BABALÚ AYÉ V. CITY OF HIALEAH: AN ANALYSIS OF FREEDOM OF RELIGION

VI. AMERICAN SOCIETY AND THE MEDIA

VII. CONCLUSION: SANTERÍA WORLDVIEW COLLIDES

WITH AMERICAN CULTURE

REFERENCES 


\section{CHAPTER I}

\section{INTRODUCTION}

"The officers, Suarez recalls, pointed their guns at the devotees and screamed at them to freeze. Suarez could hear a couple of worshipers in the front yard yelling, 'No dispare!' Don't shoot!' - Los Angeles Times 2008

On June 8, 2007, nineteen South Florida followers of the Lukumí tradition were engaged in a sacred ritual ceremony at a private residence in the City of Coral Gables, a neighboring municipality of the City of Hialeah, in Miami-Dade County, Florida. The ceremony, attended mostly by recently arrived Cuban-immigrants involved animal sacrifice. This is an important component of the Lukumí tradition. In an incident that could be described as a grossly disproportionate response to a 911 call reporting a "religious ceremony with animals," nineteen Coral Gables police units with twenty-three police officers arrived at the residence. They pointed their weapons at the elderly, children, men and women participating in the ceremony. The officers interrupted the ceremony, desecrated the ceremonial site, and detained the participants for several hours outside the home. Three hours later, the Miami-Dade County State Attorney's Office said there were no grounds for arrests, and all the police officers left. During those three hours of waiting, members of the media stood outside the home photographing, videorecording and attempting to speak to the detained worshipers.

This 2007 Coral Gables incident can be described as local law enforcement's disregard of a 1993 federal court ruling in Church of Lukumi Babalú Ayé, Inc. v. City of 
Hialeah, 508 U.S. 520 (1993) protecting this religion's freedom to engage in animal sacrifice. This ruling followed a very successful argument presented to the court by the founder of the church, Oba Ernesto Pichardo in which he outlined the religion's worldview underlying this ritual form. The court's favorable ruling legalizing the sacrifice of animals in connection with Santería then could be interpreted as its endorsement of the followers' right to practice this ritual in keeping with their worldview. In the eyes of the practitioners, Santería had gained official recognition as an American religion with its practice of animal sacrifice gaining permission from that ruling. Despite that ruling, practitioners of Santería have continued to experience ongoing harassment at the local government level. Incidents such as the Coral Gables invasion by the police in 2007 have led worshipping communities, such as the Church of Lukumí Babalú Ayé, to question American society's acceptance of their beliefs, the weight of the federal court's ruling, and the power of the United States Supreme Court. Such incidents remind Santería practitioners of their need to continuously engage in litigation to protect their constitutionally protected religious right to animal sacrifice.

While the praxis of Santería involves a variety of rituals, the practice of animal sacrifice has been at the hub of the bias of American society against the religion. The practice of animal sacrifice in the Lukumí tradition is an indispensable aspect of the religious lives of the practitioners. Animal sacrifice is also in keeping with the Santería community's worldview, and plays a central role in generating a sense of well being among the practitioners, which will be demonstrated later in this study. Happenings in their day-to-day lives would have little meaning for practitioners in the absence of this 
important and sacred ritualistic practice. As part of the religious praxis, sacrifice furnishes a model for how practitioners shape themselves to the world around them.

Presenting the Church of Lukumí Babalú Ayé as a case study, it is my argument that because of misinformed understandings of Santería's practice of animal sacrifice, local municipalities all over the United States to date have not extended Santería the Freedom of Religion right to do so affirmed by the Supreme Court's 1993 ruling. A breakdown exists between federal mandates and how local governments react to and apply those judicial mandates. In demonstrating this argument, the concept of worldview will engage our reflection in this study. The study will develop this concept as an analytical frame and show how fundamental differences between the worldview of Santería practitioners and the American host culture largely explain the breakdown between the Supreme Court ruling, legalizing animal sacrifice and local government's enforcement of public health and safety laws.

In the first chapter, the introduction and proposed content will be presented. In chapter two, I will present the intellectual framework underlying the main argument of the thesis that there exists a breakdown between the federal and local governments as it relates to this faith's right to practice animal sacrifice, and that the media has aided in perpetuating this breakdown. In chapter three, I will introduce readers to the cosmology of Santería, the centrality of animal sacrifice and the cultural logic underlying this necessary ritual. In chapter four, I will describe the birth of the Church of Lukumí Babalú Ayé in the City of Hialeah, Florida, and the city ordinances banning animal sacrifice that led the church to fight the city all the way to the Supreme Court. In chapter five, I will begin with the history of Freedom of Religion in the United States, other federal court 
rulings and Free Exercise Clause cases, and present the featured 1993 Supreme Court ruling in favor of the practice of animal sacrifice. Finally, chapter six presents numerous reports where the media weighs heavy influence in perpetuating this breakdown. In the conclusion, I will present findings, why this breakdown exists and why it may perpetuate for longer than this faith may hope. 


\section{CHAPTER II}

\section{INTELLECTUAL FRAMEWORK}

"Anyone in Florida can kill an animal for sport, food, convenience or profit, but not for an exercise of religious worship. This discrimination against religion threatens every believer." - Steven McFarland, Christian Legal Society, addressing reporters on the steps of the Supreme Court Building, Washington, D.C. 1993 - David M. O'Brien's "Animal Sacrifice \& Religious Freedom: Church of Babalú Ayé v. City of Hialeah", 2004, pg. 136

In this study I have chosen to use the concept of worldview as an organizing framework and an analytical tool to demonstrate how fundamental differences between two groups can mediate the interpretation and enforcement of the ruling of a court, even one as high as the United States Supreme Court. In his book titled "World View," anthropologist Michael Kearney argues that societies or groups are arrangements of ideas and behaviors (Kearney, 1973, 5). A group's worldview is the cognitive framework supporting its lifestyle, including its religious practices. Worldviews function as lenses through which people look at reality. They comprise basic assumptions and images and provide coherent, though not always accurate, ways of thinking about the world. Kearney identifies five worldview universals (Kearney, 3). These are notions of causality, space and time, self and other, relationships, and categorizations of reality. These are necessary aspects of any human worldview. Social behavior, social structures, 
institutions, customs and practices are consistent with a people's assumptions about the nature of the world.

In his book "The Interpretation of Cultures," social scientist Clifford Geertz agrees with other scholars, like Kearney, that a worldview is the picture people have of the way things are in their sheer actuality or their most comprehensive ideas of order (Geertz, 1973, 90). Geertz identifies another crucial component of human experience, the Ethos. He argues that rituals are sacred symbols whose meanings help communities fuse their ethos with their worldviews in a bid to render the ethos intellectually meaningful. This view would help us make sense of the cultural logic underlying sacrifices as Santería ritual forms. Geertz says the Ethos of a group is the tone or the character and the quality of its life; its moral and aesthetical style and mood. Ethos is lived experience, so to speak. According to Geertz, worldview is related to ethos in that the two dimensions of human experience reinforce one another. Rituals, such as animal sacrifice, play a crucial role in this relationship. Geertz argues that through ritual and belief, a group's ethos is rendered intellectually reasonable by being shown to represent a way of life described by that worldview. (Geertz, 127). Through ritual, communities shape themselves to their exigencies.

Building on these notions, this study will view sacrifice as a ritual of the Santería religious lifestyle ordered by the worldview Santería followers share about their reality. The study will show the meaning of animal sacrifice, how it is in keeping with Santería practitioners' way of looking at the world, and how their beliefs are deployed as members of the community seek to shape themselves to their ethos. The ethos of AfroCuban immigrants, as a group unmoored from their cultural bases, (especially those who 
constitute the membership of this church), is characterized by a host of challenges. These include struggles to adapt to life in the United States while raising subsequent generations, institutionalized racism and discriminatory actions, competition for scarce resources with other minority groups, and the constant need to remit family members back in the homeland.

In keeping with their worldview, these challenges and hardship in general are experienced and expressed in terms of the activities of a host of agents of supernatural harm, such as witchcraft, sorcery, angry ghosts and ill fate, and can be remedied if the benevolence of the orishas can be solicited. Through divination, the underlying supernatural causes of these challenges are diagnosed. Through sacrifice, the community invites the intervention of specific orishas to affect the lives of the afflicted. The orishas' supernatural hand is crucial in the alleviation of these challenges and the restoration of health and wellness for members of the worshipping community, and sacrifice is the necessary process by which this faith elicits this alleviation from the orisha.

Drawing on Geertz's idea that rituals fuse a group's worldview with their ethos and informs the latter with meaning, we can say that through sacrifices, the Santería community aligns its ethos with its worldview. In this way, it is not only able to render this ethos intellectually meaningful but it is also able to shape itself to it in practical ways. In this tradition, like others involving the ritual sacrifice of animals, the sacrifice is akin to prayer in other religious traditions, through which worshippers invite the supernatural hand of spiritual agents in the resolution of problems. Just as the hope generated through prayer can restore sanity to a worshipper who is troubled, so do 
sacrifices give practitioners of Santería a sense that they and more powerful spiritual beings are in control of their chaotic lives.

Many people in the predominantly Christian American society raise concerns about the use of animals for sacrifice based on the "cruelty" of this practice. What they perceive as cruelty to animals is viewed as the most important reason they want it more stringently regulated or even abolished. Ritual animal sacrifice has therefore often been singled out by elements of the American society, such as the media, for denunciation. It is my position that society's opposition to animal sacrifice could be traced to a misinterpretation of the meaning of sacrifice in the religious community that practices Santería and the legal and jurisprudential standards regarding the ethical treatment of animals. In other words, while the Santería community views animal sacrifice as an indispensable aspect of its socio-religious experience, vital for the production of wellbeing, American society interprets the ritual slaughter of animals as offensive to its morals and values. Yet, while disapproving of this religious ritual, they are more accepting of other forms of animal treatment that could be characterized as cruel, such as the raising of animals for fur and food consumption - as will be presented later in this study. The public's view of Santería, fueled in part by the media, often leads to harassment and other actions by law enforcement agencies and local governmental bodies that aim to prevent the religious community from sacrificing animals. Such actions, however, can be interpreted as denying a community its constitutional right to freely practice its religion.

Historically, the sacrifice of animals has been an accepted practice in many religious traditions, including the Judaic and Christian tradition. Nevertheless, there is an 
obvious stigma attached to ritualistic animal sacrifice in the Santeria religion that dates back to the time of European colonial rule when the tradition was associated with what was often referred to as "black magic" and "witchcraft" and its rituals were described as a form of "worship of demons." The public harassment of practitioners of Santería is not exclusive to the South Florida area. These incidents in Hialeah and Coral Gables are unfortunately consistent with a pattern seen in states such as New Jersey, New York, Texas, and California where, according to Oba Pichardo, there are "thousands" of Santería practitioners. Playing heavily in the Miami portion of the conflict is the fact that the dominant religious belief system in Miami-Dade County is the Christian tradition. Most local city officials, judges, members of the media and law enforcement bodies have either a Judaic or a Christian background and view Santería rituals from the point of view of their own beliefs and practices.

In seeking to understand how the dominant American culture shapes its feelings towards Santería, especially its practice of animal sacrifice, I conducted a community survey in the cities of Hialeah and Coral Gables. I surveyed one hundred Anglos, African-Americans and Hispanics of both Christian and Judaic faiths. My survey consisted of a brief but detailed questionnaire eliciting the respondents' religious affiliation and their views of animal sacrifice and the Santería religion. Responding to a question as to whether they viewed Santería as a negative religion and why, respondents overwhelmingly attributed their negative feelings about Santería to their strong feelings against the practice of animal sacrifice. Additionally, when asked what most influenced their view of Santería, the law, their education or the media, many of the respondents reported the media as the factor affecting their view. It is my opinion that it is the 
practice of animal sacrifice and the numerous negative media reports about it that have shaped how Santería is perceived in the United States.

I will later explore how most of American society thinks of Santería stems from things seen or heard in the popular media, such as newspapers, television, film and the like. The media has the power to present Santería either as an established religion or as a bizarre and cruel cult. Unfortunately the latter is usually the case as the tendency is for the media to focus on the rituals of the traditions that depart somewhat from what most Americans are accustomed to, making such traditions seem bizarre at best and malicious at worst.

The earliest depictions of Santería were featured in the 1980s in the New York Times. Headlines from May 24, 1980 and June 8, 1980, read, "Ritual Slaughter Halted in Bronx by Police Raid" and "Police seize animals prepared for sacrifice by cult in Bronx," respectively. The piece that followed reported the increasing conflict between the practitioners of the religion and the local law enforcement agents. Such headlines alone project the religion in a very unflattering light and because the article focused exclusively on the ritual forms of the tradition, they reduced the religion to just these aspects on the public's mind.

Accustomed to sensationalizing events they report, journalists use language in reporting these incidents that conveys unflattering images. To list a few examples, "They interrupted a primitive religious rite involving the ritual slaughter of animals"; "The scene encountered by the police was characterized as blood spattered confusion"; and "They found twenty-four men and women in white robes wailing and chanting in an apparent trance. There were drums beating, chickens squawking, and goats bleeding." 
Such vivid depictions generate images of Santería that seem more like scenes from a horror movie. Since the 1980s the majority of the newspaper and magazine articles about Santería have followed this pattern of focusing on events surrounding sacrifice. A sample of headlines from various newspapers read: "Animal Sacrifices: Faith or cruelty"; "A Chicken at Every Altar"; and "Authorities Credit Animal Sacrifices to Santería Religion".

The media's reduction of Santería to the ritual practice of cruel slaughtering and of its practitioners to criminals, lends for a very negative image of the religion. Such imaginative depictions cloud judgment when law enforcement agents are dealing with Santería. In spite of the Supreme Court declaration of the ritual as legal, harassments of the worshippers of this group continue at the local level. There are parallels between the tradition's practice of animal sacrifice and other practices in the dominant American society religions. Thus, Oba Ernesto Pichardo of the Church of Lukumí Babalú Ayé points out, "One can kill a turkey in the backyard and place it on a table, say a prayer and serve it, but if we pray over the turkey and kill and then eat it we violate the law." While the United States is becoming tolerant of diverse religious views, many people still become concerned when the outward actions of a religion are not seen to be in accord with how the dominant worldview defines civilization.

A good starting point in contesting this dominant position of the American society would involve an exploration of the cosmology of Lukumi, identifying the place of animal sacrifice in it, and describing the cultural logic underlying the practice. This is the objective of the discussion presented in the next chapter. 


\section{CHAPTER III}

\section{LUKUMÍ COSMOLOGY AND ANIMAL SACRIFICE}

"Institutionalization in ways of formal tribal order should serve as pillars to unite our communities worldwide. The focal point must be the collective welfare of the religion, its institutions, and not personal grandeur. The orishas are the leaders and the ministers their servants." -Oba Ernesto Pichardo, Church of Lukumí Babalú Ayé, 2004

This chapter presents a brief history of Santería, or 'Regla Lucumí,' and an exploration of its cosmology and its rituals, especially animal sacrifices. The objective is to demonstrate the role of sacrifice as a core ritual of this community. There is a sense among practitioners of Santería that there is a nexus between practicing animal sacrifice and generating a sense of well being among worshippers. In this chapter, I will explore this connection in the context of the overall worldview of the community.

The term Santería is a colonialist label attached to African-originated religious practices, flavored heavily by the Orisha worship tradition of the Yoruba people of Southwestern Nigeria. Santería arrived in the Caribbean beginning in the seventeenth century when a large number of African slaves imported from these parts of West Africa arrived on the shores of Cuba. These slaves transplanted their religious culture to this island blending it with the Catholic practices that were imposed on them. To an appreciable degree some practices of African groups from other parts of the continent, such as Congo, Angola and Mozambique also enslaved in Colonial Cuba, and even Haitian Vodou filtered into what has now become Santeria. Practitioners of the tradition 
prefer the name Lukumí, meaning "friendship," as a more appropriate way of describing the religion, and it was in Cuba that Santería became known as Lucumi (GonzalezWippler 1989, 2).

Three aspects of colonial Cuban society contributed to the survival and growth of the Lukumí tradition in Afro-Cuba: the lack of attention given to formal religious instruction especially in the countryside where most slaves resided, the institution of cabildos (religious brotherhoods) in the urban areas, and the development of Maroon settlements known as palenques on the mountainsides. These furnished slaves with space within which they were able to retain the religio-cultural practices they had brought with them and transfer these to subsequent generations. The cabildos especially have left an indelible mark on the tradition in the form of Iles of the Orishas. Iles are spaces that house Orishas and the ritual paraphernalia associated with rituals performed in their honor, as well as the loosely knit worshipping communities who occasionally gather for devotional practices. These three contributing factors shaped the Cuban Lukumí praxis and worldview that would ultimately arrived in the United States via the Cuban migration of the 1960's and 1980's (Gonzalez-Wippler 1989, 86).

Devotion in Santería revolves around the belief in one Supreme Being, Olodumare, who created the universe and all of the creatures in it. A hierarchy of spirits exists in the cosmology of Santería. Olodumare is at the top of hierarchy. The deities, also known as orishas, follow next. Orishas are agents of Olodumare in the universe. They rule over every force of nature and every aspect of the lives of human societies. Devotees approach them through prayer, ritual offerings and the orishas make their wills known often through trance-possession. Orishas are counted on to come to the aid of 
followers and guide them to a better life. Each orisha is attributed a special number and color, among other favorite things, such as a food or day of the week. The orishas have personal likes and dislikes, which can be demonstrated in a favorite color, food, drink, etc. Examples of the more popular orishas of the Lukumi tradition are Obatala, Eleggua, Orunla, Ochosi, Ogun, Oshun, Changó and Babalú Ayé. The third group of beings in this hierarchy is the Eggun, or the ancestral spirits. Human beings are next in the hierarchy, ending finally with plants and animals. Most importantly, at the center of the cosmology of the Lukumi tradition is the notion of Ashé. It is in the context of the belief in Ashé that we can make clear sense of the cultural logic underlying the practice of animal sacrifices.

A Yoruba word that literally means, "so be it," Ashé is a symbol of divine power (Gonzalez-Wippler 1989, 5). It is an energy force that all created beings have and exchange. It is impersonal, formless, shapeless, neither moral nor amoral, and limitless. Ashé is the animating force of all creatures. Believers of Santería say that without Ashé, the universe itself would come to a complete standstill. The Lukumí tradition revolves around the ability to harness Ashé and deploy it in advancing one's purpose in life. Ashé is connected to the health and vitality of a creature. To have abundant Ashé means to be healthy, happy, lucky, and in harmony with the physical environment, inner spiritual entities and the orishas. On the other hand, to lack Ashé or experience a decline in it means to be ill, troubled and, in extreme cases, to be possessed and tormented by evil spirits. The goal of life is to enjoy its blessings, and the abundance of Ashé guarantees this. The rationale behind animal sacrifices is to ensure the continuous in-flow of Ashé from an orisha to worshippers. 
Ebó is the term generally used to describe sacrifices. Ebó is the way in which a particular orisha is propitiated so he or she will give Ashé. Ebó can be an offering of fruits, flowers, candles, or any of the other favorite foods or drinks of the orishas. However, the larger offerings require the life force or blood of a lower being in the hierarchy of beings. The animating principle, the Ashé of this animal, is channeled to the orisha who deploys it in the production of welfare for the supplicants. Not only does an orisha require this force to enhance the welfare of worshippers, but the sustenance of an orisha is also contingent upon the continuous supply of Ashé from sacrifices. Orishas can become extinct if devotees starve them of Ashé. The blood of a sacrificed animal is considered the physical vessel of the life force that can replenish the orisha's store of Ashé. This explains the crucial value attached to blood in the ritual life of worshippers of Santería.

Contrary to American society's beliefs about the cruelty to which the sacrificed animals are subjected to in the Lukumi tradition, Santería practitioners claim that great care is taken to minimize the suffering of the animal. Santeros defend their practices by pointing out that the animals are put to death in a humane manner and are more often than not consumed as food. They insist that the animal has to be healthy and had to have been raised in a natural environment. Before being sacrificed, the animal is prayed over and asked for it to sacrifice its body and blood force to the orishas. Its jugular is cut with a sharp knife, cutting nerve sensation and preventing unnecessary suffering. The animal is then thanked for its sacrifice throughout the divination process. After the sacrifice, the blood force or Ashé is offered to the particular orisha and the animal is then generally eaten as part of the ceremony, except in rituals in which the sacrifice is intended to 
cleanse a ritually polluted practitioner. In such rare instances that a possession is said to exist, the carcass is charged with the transferred negative energy from the cleansed practitioner and must be disposed of. Furthermore, only Santería priests are permitted to make blood offerings, meaning that ceremonies that involve the ritualistic sacrifice of animals are only performed and witnessed by priests of this faith.

One cannot simply dismiss animal sacrifice as "cruel" without understanding what makes this faith believe in this ritual. To summarize, Oba Pichardo reported that ritualistic animal sacrifice is so integral to their faith that if a practitioner were not able to perform blood offerings and sacrifice animals, they would feel as if they are not in harmony with the world. Absent animal sacrifice, when required, they would feel as if they are sick, not doing what they can to feel better, and are also not helping out their ancestral spirits, or properly worshiping their deities. In the Lukumí worldview, taking away their need to ritualistic sacrifice animals for the orishas and gain Ashé could mean the end of the religion. To avoid what practitioners believe to be as a catastrophic consequence, Oba Pichardo defended the ritual against the City of Hialeah all the way to the Supreme Court. The church's case against Hialeah is featured later in this study. 


\section{CHAPTER IV}

\section{THE CHURCH OF LUKUMÍ BABALÚ AYÉ}

"For the purpose of this ordinance, the word sacrifice shall mean: to unnecessarily kill, torment, torture, or mutilate an animal in a public or private ritual or ceremony not for the primary purpose of food consumption. For the purpose of this ordinance, the word animal shall mean: any living dumb creature."

-City of Hialeah Ordinance banning animal sacrifice, September 22, 1987.

The case study for this thesis, the Church of Lukumí Babalú Ayé is named after this important orisha, who is said to be one of the most respected and beloved of all the deities in the Santería religion. Known to be an incorrigible womanizer and a clumsy dancer, Babalú Ayé can bring about death but is also relied upon for the cures of diseases. Babalú Ayé can either heal or bring about dreadful diseases. He is said to be in charge of the spread of AIDS in the world, and to be responsible for the health or lack thereof in the Lukumí tradition. This South Florida church became the center of attention of a federal case that was ultimately resolved in 1993. The church's service to a then troubled South Florida community during the rise of the Cuban migration of the 1980's and the challenges the church faced at that time, which remain a threat to date, are herein explored.

Though founded in the City of Hialeah in 1974 by the Pichardo Family, the Church of Lukumí Babalú Ayé did not have a physical home and address until 1987. The church did not gain either local or national recognition until nearly twenty years later after it was founded when one of its founders, Ernesto Pichardo, challenged an ordinance 
by the City of Hialeah, banning their most sacred of ritualistic practices, animal sacrifice (O’Brian, 23).

Ernesto Pichardo's family was introduced to the faith by a former slave who worked as a cook in his grandparents' Havana home. Pichardo's mother took the religion with her when the family fled Cuba for Florida in 1960 (Fausset, 2009; Pichardo, 2008). Like other young initiates, Pichardo had suffered a "serious illness" as a child and this condition was interpreted as a sign that he could become a Santería priest. The orisha called upon to heal Pichardo was Babalú Ayé. Both Ernesto and his brother Fernando were ordained in 1970. Drawing inspiration from an earlier, but futile attempt by some family members to initiate a worshipping community back in 1940s Cuba, the Pichardo brothers founded the Church of Lukumí Babalú Ayé with their mother and stepfather in 1974. They settled in the predominantly Hispanic/Cuban-descent City of Hialeah.

Describing their rationale for creating the worshipping community, Ernesto Pichardo writes,

"The purpose of the church is to maintain, own, operate, and have a secured religious place of worship, according to the teachings of the Lukumi/Ayoba religion; to hold sessions and ceremonies for the worship of ancestors; to perform traditional baptism, marriage, birth right, priesthood ordination, and death rite; to engage in certification of its ordained members; to take appropriate legal action to ensure our constitutional protection of religious freedom." (O'Brian, 27).

With this goal in mind, the church was made up of a group of Santería worshippers, mostly recent immigrants of Afro-Cuban descent from all walks of life in terms of profession, education and ages. Oba Pichardo did not offer an exact number of followers or members of the church as of today, except to say that they were in "the thousands." Most of them reportedly worship at home. He noted that it would be almost 
impossible to list all South Florida Santería followers, and highlighted that the followers of his church was only one example of the many groups practicing Santería, for example, in states like California, Texas and New Jersey. These groups practice several different transplanted derivations of Santería. In other words, there are many different groups that practice this faith in many different forms. Animal sacrifice, however, is a crucial component of the religion's praxis in any group. There are several groups of people within the Santería religion, Pichardo explained, including the initiates, santeros, practitioners and visitors. Practitioners of Santería are a loose network of worshippers who practice rituals in their own homes for the most part. They come together as a group, as they did in the 2007 Coral Gables incident, to engage in acts of devotion only when the need arises. The Santeros, Babalawos and other important ritual specialists are the hubs around which such ritual activities are organized. Often, these individuals function as godfathers and godmothers for the worshipping communities. The church of Lukumí Babalú Ayé is one of such communities.

The Pichardos' initiative to describe the group as a church was met with resistance and challenges from other ritual specialists of the Lukumí tradition. Some santeros opposed his using of the word "Church" to describe the community as this could convey a mistaken notion of the Lukumí tradition, which does not perfectly fit into the American understanding of a church as an organized group of worshippers who meet regularly within a space to engage in worship. Pichardo explained that the term was designed to make the tradition conform, if even only slightly, to the traditional understanding of religion in American society. The term does not make the group any less Cuban than other groups, for its association with the orisha in charge of health, 
Babalú Ayé, was a marker of its unique Cuban identity and a source of attraction for Santería followers. Pichardo's move can be interpreted as a contextualization of an AfroCuban worship tradition in the United States of America. However, he recognized that his efforts angered some Santería followers of South Florida, who viewed going public as sacrilegious and offensive to the orishas. They balked at paying certification and ceremony fees, and breaking their tradition of secrecy and privacy of performing in their own homes (O’Brian, 29).

Until the Pichardos secured a physical address and home in 1987, which proved only to be temporary, the church conducted initiations, provided counseling and organized santeros in South Florida in the homes of practitioners. The concern for health of the individual and the community is at the core of Santería beliefs and practices. Good health is defined in terms of the totality of well being for individuals and communities. The production of well being is in the hands of the orishas, who control all happenings in the universe, and religious rituals are mechanisms through which the agency of these beings can be pressed into service to provide good health for members. The 1980 Mariel boat lift, which resulted in the massive influx of santeros from Cuba to Miami-Dade County, contributed to the expansion of the newly created Church of Lukumí Babalú Ayé as newly arrived migrants or exiles sought sacred spaces in which to address their health needs. Demanding urgent religious attention given the chaos that occasioned their migratory process, these santeros' attention was directed to this newly formed religious community.

Reflecting on the history of the church, Pichardo equates the demands for religious services at that time to those of the county's department of health, safety and 
law enforcement. The church expanded as it responded to the massive migration and the welfare needs of the migrants. It established the Institute for New World Studies through funds provided by the Florida Endowment for the Humanities. The institute offered Afro-Caribbean religions workshops for law enforcement officials, hospitals and mental health professionals, academics, and the general public to educate them about Santería. In 1986, the Church of Lukumí also partnered with the Mental Health Association of Miami-Dade County and offered accredited courses on Afro-Caribbean religions to local law enforcement officers. These services enhanced the church's image. The church's public profile was enhanced further when in the 1980's Pichardo petitioned the MiamiDade County School Board and successfully persuaded it to allow a third grade student to miss school for a month in order to be initiated into the religion.

While the practice of sacrificing animals is an important expression of the faith of followers of Santería, members from the Euro-American host community cringe at the thought of animals being sacrificed as part of ritual processes. For others, however, the problem extends beyond the practice of a primitive ritual or cruelty to animals. Especially for those who operate the county cleanup boats in the rivers and channels, the number of decapitated goats, chickens and doves dumped on these waters was becoming a major public health problem. While the practitioners of the Church of Lukumí Babalú Ayé acknowledge this problem, there is a tendency on their part to trace it to the many new Cuban immigrant santeros. They argue that these new immigrants do not adhere to strict disposal rules of sacrificial animals within the faith. Equally important as a part of the public resentment to this ritual slaughter of animals were misconceptions stemming 
from rumor-generated fears among neighbors in the church's locale that their pets would be stolen and offered up to the orishas.

These fears and misinformation led to over five thousand individuals to sign petitions urging the City Council of Hialeah to adopt several ordinances that directly and in no uncertain terms banned all practice of animal sacrifice in 1987. (O'Brien 163-170). These ordinances made it illegal for the Lukumi tradition to engage in this ritual in the City of Hialeah, where the bulk of this faith's followers resided. These ordinances set the stage for the church's legal battles over the next six years.

The birth of a Santería church in the City of Hialeah in Miami-Dade County Florida proved helpful in meeting the spiritual and, most importantly, the health needs of the Santería migrant population of the 1980's. However, though it assisted and worked closely with the department of health and other agencies, the service of the Church to the host community did not aid in shaping a positive view of their religion. Despite their efforts to assist the host community with knowledge on how to manage the new immigrants and their religious beliefs through educational programs, the church was still met with resistance. This resistance was primarily due to new immigrants who were not adhering to the animal sacrifice disposal rules of the faith. The church had to fight for their right to engage in their inherent ritualistic practice of animal sacrifice through local council ordinances all the way to the highest court of the land. This featured case is reviewed in the next chapter. 


\title{
CHAPTER V
}

\section{CHURCH OF LUKUMÍ BABALÚ AYÉ V. CITY OF HIALEAH:}

\begin{abstract}
AN ANALYSIS OF "FREEDOM" OF RELIGION
"Believing with you that religion is a matter which lies solely between man and his God, that he owes account to none other for his faith or his worship, that the legislative powers of government reach actions only, and not opinions, I contemplate with sovereign reverence that act of the whole American people which declared that their legislature should 'make no law respecting an establishment of religion, or prohibiting the free exercise thereof,' thus building a wall of separation between church and State." -Thomas Jefferson, letter to Danbury Baptist Association, CT., Jan. 1, 1802
\end{abstract}

Thomas Jefferson's statement in a letter to Danbury Baptist Association in 1802 quoted above set the tone for the Freedom of Religion clause of the United Sates Constitution. This chapter will explore the birth of this important constitutional clause and various societal conditions that led to the inclusion of this clause in the United States Constitution, as well as several supreme court cases defending this First Amendment right, including the case of Church of Lukumi Babalú Ayé, Inc. v. City of Hialeah, 508 U.S. 520 (1993) featured in this thesis. As it will be of mention throughout this chapter, it is important to describe the hierarchy of standards the courts employ to weigh an asserted government interest against a constitutional right or principle that conflicts with the manner in which the interest is being pursued. The three-prong principle includes strict scrutiny at the top, intermediate scrutiny as the middle level, and lower level scrutiny, also known as a rational basis. Rational basis, the lowest level of scrutiny that a 
court applies when engaging in judicial review, generally refers to a level of scrutiny applied by courts when deciding cases presenting constitutional due process or equal protection issues related to the Fifth or Fourteenth amendments. The most rigorous and stringent of scrutiny, strict scrutiny is generally applied to First Amendment Freedom of Religion type cases, similar to the ones discussed in this chapter. This chapter will also make mention of several federal "tests" that have been employed when deciding on Freedom of Religion cases.

Religious activities have clashed with the legal system in this country since colonial times. During the years of early America, settlers were often escaping persecution from their mother countries, creating new religions as they settled in the United States. Religious groups were extensions of Europe, such as the Roman Catholic Church and the Church of England. Religious diversity has not meant religious tolerance for the most part in America. In the context of this ethos of religious self-righteousness, intolerance, and divergent religious discourses and praxis, some religious practitioners found themselves at odds with the legal establishment. In the colonies dominated by the Puritans, all it took for someone to be sentenced to horsewhipping, banishment, imprisonment or hanging in the gallows was to dissent from the strict dogma of the church.

From a historical standpoint, not all religious thinkers of the time were inclined towards intolerance, however. Some enlightened religious scholars were open to religious freedom, including William Penn and the Quakers in Pennsylvania and Delaware, Lord Baltimore and other English Catholics in Maryland, and Protestant dissenter Roger Williams in Rhode Island. They were among the first to become 
proponents of freedom of religion in America (Moretta, 2006). By the time the American colonies declared their independence from England in 1776, the colonies were split into two main groups: those who harbored grassroots religions and believed religion should control society; and those who believed that government should control religion (Moretta, 2006). The New England states, however, were not as open to state sponsorship of religion as the rest of the thirteen colonies were because the Congregationalists had their religion fully entrenched into the fabric of their lives. Even after the Constitution was ratified in 1789, Connecticut, Massachusetts, New Hampshire and Vermont were still giving and receiving support, legally and financially, from this church.

The movement for freedom of religion came to a turning point in the 1780 's due largely in part to the evangelicalism of Protestant dissenters and in part to the concerns of minor religions. In essence, the Baptists' fanatical praise, calls for religious freedom and most particularly the inclusion of slaves in their close knit communities and congregations drew the ire of the religious majorities in Virginia and in other states (Moretta, 2006). Some religious minorities, on the other hand, believed that the establishment of religion and prohibition of religious freedom hurt religion as a whole (Moretta, 2006). State authority over ministers, registration and licensing of religious dissenters and other dictatorial tactics were seen by the Baptists and others as stifling religious enthusiasm and initiative. Baptists believed that religion was essential to a civilized society. However, they did not believe that government should control religion.

By the time of the Constitutional Convention in Philadelphia in 1787, the call for religious freedom from government control and the right to exercise religious faith was 
reaching a fever pitch, and the debate would continue for many years. Most at odds with how the Constitution should deal with Freedom of Religion were Thomas Jefferson and James Madison. Jefferson believed in complete separation of church and state, and even ridiculed some religions, including Protestants and Catholics, for their beliefs and the way they carried out their faiths (Johnson, 1999). Madison, on the other hand, was of the firm opinion that the religion of every man must be left to his conviction and conscience.

Jefferson based his theory of religious freedom on the philosophy of John Locke (Johnson, 1999). Although Jefferson advocated religious freedom and tolerance, he saw religious intolerance and religious evangelicalism as more of an inconvenience to government and an obstruction to the Utilitarian society that he wanted America to become. Jefferson believed that the only way these religions could tolerate each other and no longer hinder the development of the country was for the government to be totally isolated from religion. He advocated denial of financial support to religions, believed there should be no promotion of religions by government officials, and opposed any form of a state-established church (Johnson, 1999). It was his belief that religious movements and evangelicals would not, in any way, cause governmental strife if they were simply left alone.

Madison's view on freedom of religion followed that of William Penn and St. George Tucker, who believed that there could be no freedom of religion without the freedom to act on that religion (Schaaf, 2004). Madison believed that it is the right of every man to exercise it as he may dictate, and that the laws of the Creator took precedence over the civil society. He felt it would be only logical for religious faith to be 
given greater immunity from state control because the state did not even have the power to control religion (Schaaf, 2004).

Though it was through Thomas Jefferson's arguments that separation of church and state was born, one could argue that its roots date to a far more ancient time than the philosophical exercises of colonial America. One might trace this to a passage in the New Testament that suggested that such division was desirable. When Jesus was asked by the Pharisees if they should pay taxes to the Roman emperor, he answered: "Render unto Caesar the things which are Caesar's and unto God the things that are God's"(Mathew 22:21). This poignant phrase can be considered an important premise for separation of Church and State.

The legal framework in American law is the United States Constitution. The First Amendment reads: "Congress shall make no law respecting an establishment of religion, or prohibiting the free exercise thereof". The First Amendment was supposed to protect all religions from excessive and unjustified governmental interference. However, it is not enough for legislation to prescribe the protection of an activity. It requires judicial interpretation of such legislation and societal acceptance of such interpretation.

The Supreme Court's first encounter with a Free Exercise Clause claim came when a Mormon polygamist in the Utah Territory challenged his conviction under a federal anti-polygamy law called Reynolds. The Supreme Court rejected the appellant's claim that his religious beliefs necessitated, and therefore excused, his violation of federal law. The Court read the Free Exercise Clause as protecting religious beliefs, not religious practices that run counter to neutrally enforced criminal laws. However, by the time of the Warren Court years of the 1960s, the Court had adopted a much more expansive view 
of the Free Exercise Clause. It compelled governmental accommodation of religiouslymotivated conduct in the absence of a compelling state interest for repressing it, and allowed for the use of those means that least burdened religious practices.

Strict Scrutiny requires the law to satisfy three principles: the law must be justified by a compelling governmental interest; it must be narrowly tailored to achieve that interest; and it must be the least restrictive means for achieving that interest. Applying strict scrutiny to laws that significantly burdened religious exercise, the Court found it unconstitutional for the State of South Carolina to deny unemployment benefits to a Seventh Day Adventist who turned down a job opportunity that included Saturday work in Sherbert v Verner, 374 U.S. 398 (1963). The ruling on this case established the Sherbert test, which consisted of four criteria that are used to determine if an individual's right to Free Exercise has been violated by the government. The court must determine whether the person has a claim involving a sincere religious belief, and whether the government's action is a substantial burden on the person's ability to act on that belief. Once these two criteria are met, then the government must prove that it a) is acting in furtherance of a "compelling state interest," and b) has pursued that interest in the manner least restrictive, or least burdensome, to religion.

The Burger Court continued to apply this Sherbert test, using it in 1972 to find unconstitutional, as applied to Amish families, Wisconsin's law mandating attendance in schools until age 17, in Wisconsin v Yoder, 406 U.S. 205 (1972). State and lower federal courts, of course, applied strict scrutiny to enjoin a variety of criminal laws in the 1970s and 80s. For example, in 1979 in Frank v Alaska, 304 P.2d 1068 (1979) the Alaska Supreme Court held that the state could not enforce its hunting laws against Athabascans 
who were religiously motivated to hunt moose out of season, moose being a key ingredient in a religiously proper funeral potlatch.

By the mid 1980s, the Supreme Court was crowded with Free Exercise Claims. While the court still utilized scrutiny, it began to take a more skeptical view of Free Exercise claims. For example, the close division of the Court on these claims was revealed in its 1985 affirming decision of an Eighth Circuit case enjoining Nebraska from enforcing a state law requiring photo identification on driver's licenses against a Nebraska motorist who believed that such pictures violated the Second Commandment's warning against worshipping graven images (Quaring v Nebraska, 472 U.S 478 (1985)). The following year, the tide turned against Free Exercise claimants when the Court rejected, 5 to 4 , the seemingly sympathetic request of an Orthodox Jewish army psychiatrist who felt religiously-compelled to wear a yamulke on duty, and who asked to be exempted from the military's ban on such headwear (Goldman v Weinberger, 476 U.S. 503 (1986)). Another Supreme Court case, Lyng v Northwest Protective Cemetery Association, 485 U.S 439 (1988), provided a major hint of the revolution in Free Exercise law to come by adopting a per se rule that the government need not concern itself with the impact that its land use decisions might have on religious practices. Based on this newly announced principle, the Court permitted the United States to proceed with construction of a road through a national forest that would concededly have severe consequences for the practitioners of a Native American religion who considered the area sacred.

These may seem considerably mild examples to the Free Exercise jurisprudence of the 1990 Smith case when two members of the Native American Church of Oregon 
were fired from a private drug rehabilitation organization and denied unemployment compensation because they ingested a substance called peyote for sacramental purposes. Peyote is listed as a controlled substance under Oregon law, making it illegal to possess unless prescribed by a doctor. Justice Scalia wrote the majority opinion stating that since peyote was illegal under general law, there was no infringement of Free Exercise. The Court again held the Jeffersonian philosophy of religious conduct that there is no absolute right to act on your religious beliefs and that if exceptions are made, a person could become a law unto himself. The Smith Court succeeded in limiting the Sherbert test and allowed states to ban religious practices that are outlawed on the basis of general applicability.

In yet another federal case determining a test of use in Free Exercise Clause, the Lemon v. Kurtzman case of 1971 determined that in order for a law to be considered constitutional under the Establishment Clause of the First Amendment, the law must: 1. Have a legitimate secular purpose; 2 . Have the primary effect of either advancing or inhibiting religion; and 3. Not result in an excessive entanglement of government and religion. Though the United States Supreme Court applied the Lemon test as recently as 2000 in the case of Santa Fé Independent School District v. Doe, it too has met its many challenges and is suspected will not be around for much longer. In the Santa Fé case, the Courts ruled it unconstitutional for high school football players to engage in prayer before their games as these games were taking place on school property, where prayer in schools is not allowed.

In 1993, in Church of Lukumi, the Supreme Court took a case which it concluded showed an attempt by government to specifically target an unpopular religious practice, 
and struck down the laws in question, all designed to deal with animal sacrifice practiced by a large but largely clandestine African-descendent religion mostly of Cubans. The Court unanimously concluded that the ordinances of the City of Hialeah violated the Free Exercise Clause.

An examination of the litigation in the Church of Lukumi case in its political, cultural and legal context adds a perspective to the debate that is worth considering. As one reads the favorable narrative a number of questions come to mind: Why did the city act as it did, even after it was warned by its attorneys that its proposed actions might be unconstitutional? Why would political figures knowingly ignore the Constitution when they had a good chance of losing in the end? Why did interest groups get involved in litigation which started as an individual's effort to deal with an immediate threat to his religious practices, and what does this indicate about the factors that lead interest groups to litigate? What does this case tell us about the nature of constitutional interpretation? Further, the specifics of this case provide a particularly compelling example of the difficulty courts face in resolving disputes generated by strong cultural differences as well as non-mainstream religious views. It illustrates as well how hard it is for a court to capture, let alone resolve, the complexities of such disputes.

The benevolent doctrine that emerged from the case of Church of Lukumi, however, enjoyed short-lived favor by the Court, which in the 2004 decision Locke v Davey, 540 U.S. 712 (2004) considered its reach in a case involving a Washington State scholarship program for gifted students. The program allowed students receiving a state scholarship to pursue any major, with one exception: a degree in Devotional Theology. When Joshua Davey, a scholarship recipient, was denied funding to pursue a theology 
program at Northwest, a private religious college, he sued, alleging that Washington had violated his Free Exercise right. Chief Justice Rehnquist, writing for a 7 to 2 majority, found that the Free Exercise Clause and Establishment Clause, read together, offered enough to allow Washington to exclude a major in Devotional Theology, a religious calling as much as an academic pursuit, from the list of endeavors it could support with taxpayer funds. Justices Scalia and Thomas disagreed, finding the exclusion to be a clear violation of Free Exercise principles laid down in the case of Church of Lukumí.

A close look at these doctrines should be sufficient to identify and explain the distinction the Supreme Court has made between religious beliefs that an individual may have versus the practices of those beliefs. The Supreme Court's decisions seem to follow a theme that a person's right to religious freedom is much easier to apply to belief than it is to the actual practice of those beliefs. The Court decisions travelled a vast spectrum of legalese and concepts that evolved from simple doctrine to complex legal dissertations. The holding that the Court was protecting religious beliefs, not religious practices, that run counter to neutrally enforced criminal laws, as expounded in the case of Reynolds, was simple enough. However, as the issues before the Court became more complex, so did the Court's holdings. This is exemplified by the case of Sherbert, where the court held that laws must compel governmental accommodation of religiously motivated conduct in the absence of a compelling state interest and the use of means that least burden religious practices. The doctrines of the Court after Sherbert then began taking a conservative turn: In the case of Yoder the Court applied the strict scrutiny test, holding that government need not concern itself with the impact that its land use decisions might have on religious practices; then in Smith the Court arrived at the conclusion that 
generally applicable criminal law raises no Free Exercise issues at all, but that a heightened scrutiny should be applied only when a law specifically targets religious practice.

Let us analyze the afore-mentioned court doctrines. First, the Court held in Reynolds that the Free Exercise clause protects religious beliefs, not religious practices that run counter to neutrally enforced criminal laws. This apparently simple concept was a preview of what was to come. In 1878 in America most of the intellectuals of the time were enamored with the liberal way of thinking, which by then had been around for more than a century. It was only natural that when a conflict arose pitting a religious practice against the law, the Supreme Court would come down on the side of the government. However, the Justices of the Court had to find a rational basis for their decision so that it could be received by the population at large as acceptable. This rational basis hinged on drawing a distinction between religious beliefs, which the Court purported to protect, and religious practices, which according to them was not protected from government regulation. The problem with this distinction is that religious practices are deeply rooted in beliefs. However, freedom of religion most often means only freedom of belief, not necessarily freedom of practice. Many times, as in the case of the Mormon Church, these practices are tenets of belief. The Court ignored this fact and denied the Mormon Church's practices with what amounted to a coup de grace, for the Mormons then reformed their beliefs to conform to the "morals" of society. For all practical purposes the Mormon Church became a completely different religion. This was a violation of the Free Exercise clause, as the immediate effect of that law as upheld by the Court's decision was to eliminate a religious practice. Illustrating the contradicting arguments of 
Jefferson and Madison's position on Freedom of Religion, this case presented the absence of separation of church and state, while the other advocated for faith to be the decision of the man.

Second, in Sherbert, the Warren Court lessened the grip that the courts had placed on religious practices and held that laws must compel governmental accommodation of religiously motivated conduct in the absence of a compelling state interest, and the use of means that least burdened religious practices. While this appeared to be a respite of the doctrine of Reynolds, it still left the door open for practices that would be regulated. Once again, even the ultra-liberal Warren Court issued a veiled threat to religious practices that were counter to a compelling State interest. Once again, some government interference in religion was sanctioned by the Court.

For a while, it appeared that the strict scrutiny standard from Sherbert, with all its potential shortcomings notwithstanding, would prevail as the law of the land. This doctrine helped the "religion side" of litigation throughout the Burger years and no case involving a compelling state interest was heard by the Court. But this felicity was not to last, and in the 1980s the Court started to chip away on the gains of the Warren/Burger years. A slew of cases dealing with religious practices made it to the Court during this time, and almost every single one was decided against the religious litigants. This trend culminated with the decision in Smith, which basically held that if a criminal law is applied generally, it raises no Free Exercise issue at all. Interestingly, the Smith Court had been praised by the religious establishments, which in and of itself revealed that religions do not necessarily have common agendas. 
This is the current state of the law, at least as interpreted by the Supreme Court, in what concerns the free exercise clause. The problem with this doctrine is that American judicial decisions and public discussions about religious freedom tend to focus on matters of individuals' rights, beliefs, consciences, and practices. The distinctive place, role, and freedoms of groups, associations and churches have often been overlooked.

In the specific case of Church of Lukumi, the ramifications of the Supreme Court's decision did not even permeate to society at large before its main tenets were obliterated by a subsequent decision. The federal view of what should constitute religious freedom, as stated in Church of Lukumi, never reached completely the hearts and minds of the regular "Joe in the street," let alone the local governments and police that are supposed to enforce and protect such laws. American jurisprudence, especially Supreme Court decisions, should usually reach the intended target with swift speed and precise mandates. In theory, what should happen does not always play out in practical terms. For example, clear Supreme Court decisions that may deal with constitutional criminal procedure issues such as "Miranda" rights may be swift. However, when the decisions include varying worldviews especially in light of our pluralistic American society, the Supreme Court's decisions may take time for society to work out the details of the competing moral interests. For example, the landmark decision of Brown $v$ Board of Education, 347 U.S 483 (1945) swam all the way against the current to change the existing morals and attitudes of people. This federal ruling took about thirty years to take effect, and it may even be questionable to date whether full desegregation exists. Brown is a perfect example of how Supreme Court rulings take time to be accepted when worldviews collide. 
In Brown, the court put out a very specific holding: "separate educational facilities are inherently unequal". Although federal law prohibited segregation, it did not issue a direct mandate for integration. In other words, an order of the Supreme Court to desegregate schools did not lay out a smooth plan to integrate them. On the contrary, in Virginia, Senator Harry Byrd, Sr. organized the Massive Resistance movement that included the closing of schools rather than desegregating them. In 1957, Arkansas Governor Orval Faubus called out his state's National Guard to block black students' entry to Little Rock High School. President Eisenhower responded by deploying elements of the $101^{\text {st }}$ Airborne Division from Fort Campbell, Kentucky to Arkansas and by federalizing Faubus' National Guard. Also in 1957, Florida's response was mixed; its legislature passed an Interposition Resolution denouncing the decision and declaring it null and void. But Florida Governor Thomas Leroy Collins refused to sign it arguing that the state must follow the Supreme Court's ruling. It took all these efforts, with Federal troops and federalized national guardsmen enforcing this historical ruling, for all states to finally adopt the Supreme Court decision.

The Brown decision and more broadly the civil rights movement are clear examples of what may happen when the Supreme Court rules one way, but American society takes time to conform with that ruling. This is similar to what has happened with the decision in Church of Lukumi. Still almost twenty years after this federal ruling, municipalities and states continue to enforce laws and ordinances prohibiting animal sacrifice in clear violation of the Supreme Court decision. This may be explained by the blinding effect that the law has on religious beliefs, especially when those religious 
beliefs are considered inferior, barbaric, ignorant, and contrary to the moral and ethical value of American society.

I do not pretend to equate the effects that a segregated society has on the ethical and moral attitudes of a civilized society with the effects of restricting a religious practice. I do intend to point out the spiritual impact that such restrictions place on the spirituality of a specific group. It is my position that the closed mindedness that brewed intolerance towards a fully integrated society during the Brown case is the same closed mindedness that does not accept animal sacrifice as a legitimate religious practice even after a federal ruling. Practitioners of the Lukumí tradition and of other Santería and African Diaspora religions still suffer persecution when animal sacrifice is involved. Without follow-through from the media outlets that are supposed to report the truth and educate the public, and without strong local governmental enforcement, the predicament of Church of Lukumí Babalú Ayé's case is a prime example of what happens when federal mandates that are supposed to be the law of the land go against mainstream ideology. From a jurisprudential viewpoint, the law may in fact be correct, but society's morals and values need time to evolve to be consistent with and supportive of the federal mandate.

Having won their Supreme Court appeal in 1993, practitioners of the Lukumí tradition should feel that their rights are safely protected by the mandate of the Supreme Court. Unfortunately, this has not been the case. Despite the ruling by the Court that animal sacrifices as a religious practice were protected by the Free Exercise clause, the decision seemed to fall on deaf ears. After 1993 and up to 2008, statutes and ordinances dealing with animal sacrifices, and frequently criminalizing it, continued to be enforced 
even if the sacrifices were performed in a religious ceremony. Across the board in the Unites States cases keep turning up. In Texas the City of Euless prosecuted a Santería priest for violating animal sacrifice laws (Merced v. City of Euless, 2008 U.S Dist Lexis 3685). In California the City of Torrance is also prosecuting a Santería practitioner for sacrificing animals. Similarly, in New Jersey, a man was arrested and charged with animal cruelty after he was observed handling the carcasses of dead animals used in a sacrifice. Most recently, as described above, the City of Coral Gables Police Department in Florida raided a home where a Lukumí tradition ceremony of animal sacrifice was taking place. Worshippers were detained for hours while the Police Department investigated.

All these examples highlight a secondary problem with the law vis a vis religion: Sometimes American society will not accept a ruling by the Supreme Court if the religion sought to be protected is perceived as primitive, pagan or barbaric. Scenes like what happened in South Florida on June $8^{\text {th }}, 2007$ keep surfacing all over the United States, and will surely continue to surface for as long as the federal government remains oblivious to the violation of Supreme Court doctrine.

Some states and municipalities, however, are taking steps to rectify this trend. The State of Florida, in a surprising move, has passed legislation intended to standardize the freedom of religion doctrines of the Supreme Court. Although the Free Exercise Clause of the First Amendment was incorporated into the states through the Fourteenth Amendment, as long as a state was not limiting or taking away the rights as interpreted by the government, the state was free to experiment and give its inhabitants more rights than what the federal government is willing to offer. 
This is exactly what Florida did in 1998 when the state created the Florida Religious Freedom Restoration Act (FRFRA). Much like the federal version of this act enacted after Smith and overruled in 1997's City of Boerne v. Flores, this statute employs the compelling interest test in deciding whether a law that infringes on Free Exercise rights should be struck down. However, government action must also be a "substantial burden" on religious freedom. Essentially, in order to prevail under the FRFRA, the state must not have a compelling state interest, there must be less restrictive means of regulating the conduct, and the government action must be a substantial burden on practicing the religion. In passing this statute, Florida actually gave its citizens broader rights than the federal government was willing to offer; but plaintiffs who have brought claims under the FRFRA have not been as successful as one would think with a law as broad as the FRFRA, mostly because plaintiffs have failed to meet the substantial burden test.

In addition, Florida has also specifically exempted ritual slaughter of animals from its animal cruelty statute. Florida Statutes $\S 828.22$ states, "Nothing in ss. 828.22828.26 shall be construed to prohibit, abridge, or in any way hinder the religious freedom of any person or group. Notwithstanding any other provision of ss. $828.22-828.26$, in order to protect freedom of religion, ritual slaughter and the handling of livestock for ritual slaughter are exempted from the terms of ss. 828.22-828.26." This is a major step towards possibly addressing the breakdown.

Other municipalities are following the lead of the government of the State of Florida. The metropolitan government of Miami-Dade County has included in its police training manuals the issue of dealing with practitioners of the Lukumi tradition, 
specifically dealing with calls that concern ritualistic animal sacrifice. Officers are now made aware of the Supreme Court decision in Church of Lukumi, of the Free Exercise Clause of the U.S. Constitution, and the Florida Humane Slaughter Act, $\S 828.22$. The City of Hialeah finally seems to have learned the lesson as well and, with the help of prominent members of the Lukumí Church, has enacted ordinances that also take into consideration the issue of ritualistic animal sacrifice. Most interesting is the language in the preamble to Hialeah Code $\S 10-2$, which reads "Whereas, being mindful and tolerant of the Constitutionally protected right to the free exercise of religion and the protection this right affords to ritual slaughter..." While this may not be enough to change the minds of the citizens of Hialeah, it is a good starting point in bridging the legal gap between federal and local breakdown.

Conversely, other municipalities should heed the example of the City of Hialeah. Many laws and ordinances still remain on the books, and are actively enforced, that go counter to the decision in Church of Lukumi. For example, still to date, the Los Angeles Municipal Code $\S 53.67$ states "(a) No person shall engage in, participate in, assist in, or perform animal sacrifice. (b) No person shall own, keep, possess or have custody of any animal with the purpose or intention of using such animal for animal sacrifice. (c) No person shall knowingly sell, offer to sell, give away or transfer any animal to another person who intends to use such animal for animal sacrifice." While there is an attempt to correct the prohibition and conform to the Supreme Court ruling with this language "(d) Nothing in this ordinance shall be construed to prohibit any person or establishment lawfully operating under the laws of this city and state from lawfully engaging in the slaughter or ritual slaughter of animals where the preparation or killing of such animals is 
primarily for food purposes," it is obvious that the qualification that the killing be primarily for food purposes makes it non-compliant. If the City of Los Angeles really wants to be compliant with federal law, it will have to further amend $\S 53.67$.

If one compares the resistance that American society, and even governmental entities such as the City of Coral Gables, the City of Los Angeles, and others still demonstrate in accepting animal sacrifice as a protected religious activity with the eventual federally mandated acceptance, it becomes obvious that religious freedom for the Lukumí tradition is not considered a main objective in this country. We have, however, come a long way since the time when Thomas Jefferson promoted freedom of religion and made it part of our constitutional rights. We have also come a long way since the many claims against the Free Exercise clause were heard by our Supreme Court. Though it is now nearly twenty years since the practice of animal sacrifice was constitutionally protected for the Santería religion and Lukumí tradition, Santería is still plagued by the negative worldview its sacrificial practices create for it. And it is most likely because of animal sacrifice that freedom of religion is not a right fully extended to the Lukumí tradition in the United States.

In summary, freedom of religion was an integral part of discussions by the founding fathers of this nation, and was ultimately ensured for every person residing in the United States via the Constitution. Contrary to the intent of the constitutional framers of this country, however, religious freedom cases have had different forms of constitutional scrutiny applied to them over the years. In almost all cases regarding freedom of religion, it is apparent that the Supreme Court has less of an issue with religious beliefs and more of a problem with how those beliefs are practiced. It is in the 
practice of religious beliefs where worldviews seemingly collide. Our Freedom of Religion conflicts between freedom of belief and freedom to practice. Regardless, it was clear and established law that the Supreme Court interpreted both the belief and the practice of animal sacrifice in a religious ritualistic context as being constitutional with its 1993 decision. Nonetheless, to date American society has not seemingly conformed to that decision. The breakdown between the 1993 federal mandate and local governmental authorities in the Lukumí matter demonstrates the clash of religious worldviews when the minority worldview infringes upon the dominant worldview.

Nevertheless, it is important to note that although the Supreme Court ruled that the City of Hialeah officials were wrong is targeting the ritualistic sacrifice of animals and upheld the right of the religion to engage in this inextricable practice, it never gave a road map of where, when and how this practice would be carried out. In this rare instance, the Supreme Court upheld the practice. However, the line between where the legal right to sacrifice animals in the name of religion starts and where the infringing on other rights in a pluralistic American society ends has not yet been defined. In other words, one must also consider that the Supreme Court's ruling did not intend to allow animal sacrifice rituals to be performed in any manner and with no regard for other people's rights. It is at this particular juncture that the two worldviews seem to collide from a legal perspective. It is fitting to conclude this chapter on the law as it applies to freedom of religion by stating that the resolution of this issue is not in whether animal sacrifice is allowed, but rather as in many instances that include legal interpretation in our American societal worldview, in which "the devil may in fact be in the details." 


\section{CHAPTER VI}

\section{AMERICAN SOCIETY AND THE MEDIA \\ "Bad Publicity Is Better Than No Publicity."}

In the Lukumí religious tradition, followers deeply believe that animal sacrifice is performed as a means of appeasing deities or obtaining a favorable outcome. This ritual practice is based on a cosmology that is parallel to traditional American religions where there is an offering of something, like a promise, while asking and praying for a desired, favorable outcome. In American Christian society, however, anything that departs from traditional religious practices is generally viewed with suspicion. Animal sacrifice is particularly viewed as inferior and demonic though this ritual is not exclusive to Santería. Many cultures have practiced animal sacrifice at some point in their history, including the Egyptians, the Romans and the Aztecs. In Christianity, the ultimate sacrifice is performed every Sunday as priests rehearse the Eucharist. In traditional American Christian religious culture, the Eucharist is actually believed to represent the flesh of Christ. Despite historical and standing similarities in practices, traditional American Christian society is strongly at odds with the specific practice of animal sacrifice, and the American media has facilitated this dissenting view of the practice.

Media reports on animal sacrifice in Santería depict the practice as a form of animal abuse yet, as previously reported, ceremonies involving this ritual require the animals to be treated with utmost respect and are sacrificed in a humane fashion. In American society, situations where animals are raised and slaughtered for food consumption attract very few negative media reporting. American society accepts the 
raising and killing of animals for feeding, but frowns upon the same practice if it is performed as part of a religious ceremony. In that most sacrificial animals are consumed by Santeria practitioners, we can suggest that there is a double standard implied in the societal condemnation of Santería's animal sacrifices. The number of animals being slaughtered daily and the precarious conditions in which they are raised do not prompt the media outrage that ritualistic animal sacrifice attracts.

American society consumes eight ounces of meat a day, roughly twice the global average (Bittman, 2008). At about five percent of the world's population, we raise and kill nearly ten billion animals a year, more than fifteen percent of the world's total consumption (Bittman, 2008). Raising meat uses a great many resources. An estimated thirty percent of the earth's land is directly or indirectly involved in livestock production, according to the United Nation's Food and Agriculture Organization, which also estimates that livestock production generates nearly a fifth of the world's greenhouse gases. That is more than the total greenhouse gases produced by automobiles, airplanes and trains combined.

The way that livestock is raised could also prompt a media debate. Pigs are kept their entire lives crammed into cages that have railings for a floor so that their excrement can be washed away easily. Calves destined for veal production never walk more than a few square meters in their short existence. Chickens are raised in filthy conditions, one on top of the other in small cages where they pluck incessantly at each other and with artificial light resembling daylight so that they feed constantly to be ready for the market in six weeks. Some consumers now look for labels that say "cage-free" or "free-range" when buying poultry products. The United States Department of Agriculture defines 
"free range" as "poultry that have been allowed access to the outside." So a free range could be a barn crowded with chickens with a small patio where they could venture out, though most seldom do, as they have spent their entire lives in the barn and the outdoors scares them (Michael Pollan, 2007). Similarly, a free range could be a pen next to a dumpster behind a poultry market. Cage-free is not a legal term and could mean anything. Still, no matter how the animal is treated, the inescapable conclusion is that ultimately it will be slaughtered for consumption. Yet, this treatment of animals, which many could argue is a form of animal abuse, is not condemned by American society or the media as stringently as is the religious ritual of animal sacrifice. American society's negative attitude towards animal sacrifice seems to do more with intolerance than that of a genuine quest to protect animals.

Oba Pichardo reported that it would be nearly impossible to pinpoint the number of Santería practitioners in the United States or how many ritualistic animal sacrifice ceremonies take place each year. However, what is clear is that the number of animals sacrificing their lives for the health and safety of a Santería practitioner during a ritual religious ceremony would be very small in comparison to those of animal slaughter practices, such as the raising and killing for food consumption. It would seem however, that the media is silent over these situations. Other exploitive treatments of animals that take place daily throughout American society that the media shows little interest in highlighting include the use of animals for labor, raising and training animals to work at circuses, racetracks, variety shows, and keeping animals for exhibition at zoos, just to name a few. People also abuse animals through game hunting for sports, lab-testing, and raising them for furs. Yet these practices rarely receive negative scrutiny. Some 
chickens and dogs are even raised solely for fighting and gambling. None of these practices could be considered to enhance the spirituality of those who practice them, yet they are readily accepted by American society.

Santería has faced its many challenges since the beginning of the Cuban Diaspora, including its share of mostly negative media attention. The widely known statement that "bad publicity is better than no publicity" does not apply to Santería, as it has all been bad publicity with no positive spin. Santería has continuously fascinated print media, radio and TV for decades. As Mercedes Sandoval so eloquently puts it, "The phenomenon of white santeros has been especially puzzling to the press" (Sandoval 2007, 331). The Humane Society of the United States (HSUS) has been contacted by individuals who have come across sacrificed animals in rivers, at intersections, by railroad tracks, and in other places right here in Miami and elsewhere in the United States. Local law enforcement departments have also been contacted by individuals denouncing Santería practices, as highlighted in the Coral Gables 2007 incident.

These interactions between police and Santería practitioners have also brought negative visibility to Santería because the press has been eager to cover these esoteric practices and inform the public about them with its own biases. Because the negative publicity about the Santería religion is largely focused on their practice of animal sacrifice, it can be easy to deduce that the core problem American society has with Santeria is their view of that practice as being "animal cruelty." While having the enormous power to distribute the message that such religious practices are clearly allowed by the constitutional right of Freedom of Religion, the media has instead done an outstanding job over the years of presenting Santería mostly for all of its perceived bad 
and evil thereby helping to shape the worldview that has been adopted by American society.

While knowledge of the Lukumí tradition is available for education, Lukumí still suffers strong opposition from American society because of their practice of animal sacrifice. In my opinion, American society's negative perception of Santería is largely reinforced by the media. The media, and the animal rights advocates outcries that sells a lot of newspapers, are a significant contributing factor in the breakdown between federal and local government. The media aided local municipalities' lack of adherence to the 1993 Supreme Court ruling affirming Santería's right to practice animal sacrifice.

Not only are municipalities not recognizing Santería's right to exist, but their leaders also continue to view and portray Santería negatively. A January 22, 2009, Miami Herald article titled "Boring ranking misses soul of Hialeah" (Roth, 2009) quoted Hialeah Mayor Julio Robaina as having said that a recent listing by Forbes Magazine of Hialeah as a 'boring' city was "due to three decades of bad publicity. The Mariel arrivals in 1980; past government corruption; the brawl between City Hall and the Lukumí Babalú Ayé Church that was settled in 1993 by the U.S. Supreme Court; the scandals over absentee ballots." The inclusion of the historical 1993 case by the Church of Lukumí Babalú Ayé against the City of Hialeah amongst the negative publicity the Mayor chose to highlight in order to explain why the City is viewed as lacking in culture clearly indicates the City's continued negative attitude toward Santería and the media's own continued support of this longstanding trend toward the religion. As the leader of this city and its governmental figure, Mayor Robaina's choice of words in calling this precedent-setting federal case a "brawl" significantly minimizes its meaning and effect. 
In February 2003, a University of Rochester religious class conducted a study titled "Religion in American Newspapers: A Critique and Challenge", in which they reviewed religion stories published by top U.S. newspapers, including New York Times, Washington Post, Los Angeles Times, Chicago Tribune, Dallas Morning News, Boston Globe, Atlanta Journal-Constitution, Denver Post, Wall Street Journal, Seattle PostIntelligencer and USA Today. The study reported that "when it comes to religion, the press seems at odds with itself. On one hand, religion pervades America's newspapers as part of the background on topics from politics and economics to sports and the arts. On the other hand, stories about religion itself infrequently address religion's beliefs and values." The religion stories reviewed largely ignored many faiths, such as Santería, and indeed failed to tap into the faith's beliefs. With such a controlling interest of the world population, the media is then largely responsible for the perception of the worldview of Santería. Today's media enjoys a wealth of dissemination outlets that includes visual (TV and print), audio (TV and radio), and electronic (Internet, email, PDAs) media. With so many outlets and information vehicles available, the media's ability to educate and inform the public on religions' beliefs and worldview is extensive. Yet, in an apparent effort to quench the public's thirst for sensationalism that they themselves have created over the years, the media's message about Santería unfortunately continues to be negative.

In media reports involving animal abuse, there is usually some commentary from either or both of the two largest animal protection organizations, the ASPCA (American Society for the Protection of Cruelty to Animal) and the HSUS (Humane Society of the United States). Commentaries are found from these two organizations in almost every 
instance of media reports involving Santeria's practice of animal sacrifice. Along with the media, these organizations' lobbies also influence local, state and federal governments.

In existence since 1866, the privately funded ASPCA garners much support from the media and the government. The HSUS is the nation's largest animal protection organization. Both of these organizations spend much of their focus in strengthening their legislative lobby, litigation and advocacy programs. While their financing may not be their strength, they do garner much attention because, as previously stated, the media usually turn to them for comments when cases of animal sacrifice arise. Since 1993, several municipalities in the states of California, New Jersey and Florida have had a rash of media reports involving animal sacrifice, all with commentaries from the animal rights lobby. Naturally, all of these media reports have related back to Santería in an unfavorable manner, and reinforced the public's worldview and persistent negative perception of the tradition. Santería does not enjoy a wealth of lobbying influence or dollars, and it is therefore impossible for Santería to "compete" with the media's constant negative reports of their practices.

One media report came out of Passaic, New Jersey, in 2003, when a Santería priest was arrested for killing two roosters and a lamb at an altar behind his religious supply store on the city's main street. The American Society for the Protection of Cruelty to Animal (ASPCA) and HSUS promoted a call-to-action to their membership, which was highly publicized, calling for members to demand the prosecution of the priest for killing the animals. Both organizations referred New Jersey's animal cruelty statute, which prohibits the "needless killing or cruel treatment of a living animal." The ASPCA 
officials were quoted in an October 24, 2003, online article as finding the priest's actions to be "illegal" and prosecutable. In response to the priest's defense that the animal sacrifice ceremony he conducted was protected under the 1993 Lukumi v. Hialeah federal ruling, an HSUS official commented, "The Hialeah decision does not give anyone the right to commit animal cruelty." (www.HSUS.org, 2003). This is a powerful statement illustrating the lack of acceptance for the federal ruling.

The 2007 incident in the City of Coral Gables, Florida, when twenty-three police officers responded to a call from a neighbor stating that he had "heard an animal squeal" and knew there was a religious ceremony taking place at the home in question, is only one of hundreds of media reports about Santería. In 2008, the media had reports out of Orlando, Florida of a man whose residential development would not allow him to stay because of animal sacrifice practices. Media reports that year also showed that in the City of Euless, Texas, litigation was underway relative to land use ordinances limiting and prohibiting Santería's right to practice (Merced v. City of Euless, 2008, U.S. District, Lexis 3685). Other reported cases in the cities of Tallahassee, Florida, Aberdeen, New Jersey, Houston, Texas and Middletown, Connecticut in 2002 and 2003 point to actual police arrests of Santería priests for engaging in animal sacrifices, and investigations relative to disposal of animal carcasses. Online reports also showed the City of Los Angeles, California, has in its municipal code $(\$ 53.67)$ specific and direct language for the prohibition of animal sacrifice. This ordinance is in clear contravention of the ruling in Church of Lukumi Babalú Ayé v City of Hialeah. It represents an unconstitutional ban for this integral and inextricable practice in the Santería religion (Volokh, 2008). 
The disregard of a federal mandate by animal-protection and law enforcement agencies, and the fact that municipalities like in the states of Texas and California still have ordinances directly aimed against Santería demonstrate that nearly twenty years after the court's decision, municipalities' charters and police procedures manuals are outdated and ill-equipped for handling calls of this nature. It would appear that countless municipalities have simply chosen to ignore the 1993 Lukumi v. Hialeah decision, and have obviously not enacted and enforced reform to incorporate the federal mandate to extend Santería's animal sacrifice practice the permission it should be afforded under the law. While American society's feelings about and perception of Santería is historically negative, the media has played an important role in fueling and perpetuating that negativity. 


\section{CHAPTER VII}

\section{CONCLUSION:}

\section{SANTERÍA WORLDVIEW COLLIDES WITH AMERICAN CULTURE}

"The Free Exercise Clause commits government itself to religious tolerance, and upon even slight suspicion that proposals for state intervention stem from animosity to religion or distrust to its practices, all officials must pause to remember their own high duty to the

Constitution and the rights it secures. Those in office must be resolute in resisting importunate demands and must ensure that the sole reasons for imposing the burdens of

law and regulation are secular. Legislators may not devise mechanisms, overt or disguised, designed to persecute or oppress a religion or its practices. The laws here in question were enacted contrary to these constitutional principles, and they are void." Justice Kennedy's 1993 concurring opinion (O’Brien, 145).

This thesis proposes that since the 1993 unanimous ruling in favor of Santería's practice of animal sacrifice, so eloquently concluded by Justice Kennedy quoted above, there has been a breakdown between what the Supreme Court ruled and how local governments interpreted, and in many instances have ignored, the ruling. In Santería's worldview, animal sacrifice is necessary for its practitioners in order to appease the orishas and harness Ashé, an energy force of divine power. From an American cultural view point, animal sacrifice is barbaric and unacceptable. As an integral component of Santería's worldview that is viewed negatively by society, animal sacrifice then furnishes the context for this breakdown. Despite the 1993 ruling calling the Hialeah ordinances 
banning animal sacrifice "an attempt by government to specifically target an unpopular religious practice", there still exists cities like Los Angeles, California whose city charters include ordinances specifically banning this practice. American society continues to harass practitioners for this ritualistic practice. There lies the breakdown between a federal ruling and local governments' failure to adhere to federal rule.

Santería ceremony incidents like the 2007 Coral Gables case are victims of the breakdown, but also serve as a stage in which to witness the collision of Santería worldview with American culture. On one side, Santería practitioners exercised the worldview of their faith; while on the other side, local government engaged in behaviors reflecting their cultural assumptions about Santería as a primitive and barbaric religion. Setting the stage for yet another breakdown illustration, I had the opportunity to observe a Santería ceremony that also fell victim to the breakdown in 2008 . This ceremony took place at a party warehouse in Southwest Miami-Dade on a cool November evening. It was a ritual required for Obatala, the oldest and most important of the orishas for the Lukumí tradition. Dressed generally in white, participants arrived in small groups, greeting each other warmly as they entered the ceremonial room, which was dressed in white and red, Obatala's favorite colors. Participants mingled with each other, and children played, while all waited for the drummers to prepare themselves and commence the ritual.

Drumming is a most important part of divination ceremonies, and a way of life for Santería practitioners. One of the three drummers, the chanter of the ceremony was AfroCuban. He wore a black t-shirt that had several silver chains on its front with big gold letters that read: "Where is my key?" This anti-slavery display seemed most appropriate 
for this faith, given that this religion was rooted and born out of African tribes and slave trades. In Lukumís worldview, the drumming signals the beginning of the ritual. In American society's worldview, the drumming is a sign that there is Santería going on somewhere near them and they should call the police.

Soon after the drumming began, three Miami-Dade Police Department cruisers arrived on the scene. They parked their cars blocking the one entrance and exit leading to the ceremony site, and also blocking the one-way street. Nobody was able to enter or leave the premises. The six police officers milled about on the outside and did not enter the ceremony area. In an apparent attempt to find probable cause to enter, the officers strategically began to note down and call in the license plates of every vehicle parked at the event. When Oba Ernesto Pichardo approached them, introduced himself to the officers and stated their business, one of the officers said they were responding to a report about a stolen vehicle. After completing their check on all the cars parked on that block, the officers still stood around talking for about an hour, still blocking the entrance and exit, before finally leaving the site.

Most rituals observed in the Santería religion, like this one, do not involve animal sacrifice. It may be because of the preferred and often secretive nature of Santeria that these ceremonies are not generally known to American society. However, its persistently negative attitude toward this religion has also left Santería no choice but to practice in secret. Though not all Santería ceremonies involve animal sacrifice, case law, literature and numerous media reports presented here reflect that it is largely because of this ritualistic practice that police departments and American society in general still view Santería through negative lenses. 
As they have for centuries, Santería practitioners exercise their faith in line with their Lukumí worldview. As it too has for centuries, American society's view of Santería continues to be a negative one. Both groups' ethos are rendered intellectually reasonable to themselves as both indeed represent their way of life as described by their worldview. One side believes they need ritualistic animal sacrifice to survive. The other side compares animal sacrifice to animal abuse, and believes it to be barbaric and unacceptable. These two differing worldviews collide and the endless media reports help perpetuate their differences.

If Santería's worldview did not collide with mainstream American culture, there would have been no need for a federal case and no breakdown for that matter. If there was no breakdown, there would be no sensationalist media reports of police response to sacrificial sites. Until such time as Santería is more favorably reported on by the media and in turn more accepted by American society, this breakdown will continue to exist. So long as the Lukumí worldview collides with American cultural assumptions about animal sacrifice, this breakdown will persist. Until then, freedom of religion for Santeria and its practice of animal sacrifice will not be so free, and will exist only to the extent that American society, the media, and the thousands of municipal laws choose to allow. 


\section{REFERENCES}

The A.C.L.U.'s Most Important U.S. Supreme Court Victories, The American Civil Liberties Union, 1996.

The Aelion Firm, "Victory With Police in Pursuit of Religious Freedom," news release, 21 July, 2008.

Animals and Religion: A guide to issues, organizations and experts, http://www.religionlink.org/tip_080918.php, September 18, 2008.

"ASPCA \& HSUS Demand Cruelty Charges in Passaic, New Jersey Animal Sacrifice," HSUS.ORG. 24 October, 2003.

Awolalu, Omosad J. "Yoruba Sacrificial Practice." Journal of Religion in Africa Vol. 5, Fasc.2. (1973): 81-93.

Ayorinde, Christine. 2004. Afro-Cuban Religiosity, Revolution, and National Identity. USA. University Press of Florida.

Balmeseda, Liz. "You Can Fight City Hall," Miami Herald.com. 27 October, 2008.

The Becket Fund. "Santeria Rights Defended," Associated Press. 9 April, 2008.

Benedict, Gerald. The Watkins Dictionary of Religious and Secular Faith. London: Watkins Publishing, 2008.

Bittman, Mark. 2008. USA. The World, Rethinking the Meat. Guzzler.

Brown, David H. Santeria Enthroned: Art, Ritual and Innovation in an Afro-Cuban Religion. London and Chicago: The University of Chicago Press, 2003.

Carmody, Denise L. and T.L Brink. Ways to the Center, 6th Ed. Canada: Thomson Wadsworth, 2006.

"Church of Lukumi Babalu Aye Retains Attorney David Aelion for Sunshine Request on City of Coral Gables Police Department Records" Media Record, 20 May, 2008.

City of Hialeah, Hialeah, FL. Hialeah's Demographics and Business Statistics. Doc Demo 1807.

City of Hialeah Ord. Sec. 10-2.

City of Los Angeles Municipal Code, Sec. 53.67 (1990).

Clary, Mike. "Santeria Leaders Hope Tolerance of Faith's Rituals Spreads-Humane Animal Killings in Ceremonies are Permitted Under U.S. Constitution, "South Florida 
Sun-Sentinel. 27, July, 2008. http://Sun-sentinel.com/news/local/broward/sflslbsanteria0727sbjul27,0,3988833.story.

Carmody, Denise L. and T.L Brink. Ways to the Center, 6th Ed. Canada: Thomson Wadsworth, 2006.

Consejo de Latino Unidos, "Consejo and T.E.J.A.S. Announce Free Medical Aid for Residents Near Valero Blast," Market Watch. 5 August, 2008.

Coral Gables, Coral Gables, FL. Demographic Comparison-2008 Estimate. Claritas, Inc., July 2008 .

Diaz, Madeline Bara. "Santeria Leader Teaching Class on African Religion at F.I.U.," South Florida Sun Sentinel. 14 September, 2007.

De Leon, Jessica, "Federal Case Pits Religious Freedom and Ban on Cruelty to Animals," Star-Telegram-Northeast. 10 March, 2008.

De Valle, Elaine. "Santeria Church Sues Gables Over Visit From Police, " Miami Herald.com. 9 July, 2008.

De Valle, Elaine. "Gables' Manager Admits Keeping Public Records From Press, "Miami Herald.com. 31 July, 2008.

De Valle, Elaine. "A Coral Gables Employee Wants City to Remove Reprimands From His File "Miami Herald.com. 22 June, 2008.

De Valle, Elaine, "New Allegations against Gables City Manager, "Miami Herald.com. 7 June, 2008.

De Valle, Elaine, "Santeria Priest Ready for Fight with Gables," Miami Herald.com. 25 May, 2008.

De Valle, Elaine. "Letter Ratchets up Heat on Coral Gables City Manager," Miami Herald.com. 5 June, 2008.

De Valle, Elaine. "The Santero Next Door," Miami Herald. 15 August, 2007.

De Valle, Elaine, "Santeros Complain About Coral Gables Police," Miami Herald.com. 28 June, 2007.

Del Marmol,Sebastian. "City v. Santeria Continues With Latest Lawsuit, "Coral Gables Gazette. 10 July, 2008. http://www.cggazette.com/index.cf?dsp=news.view\&nid=307.

Desmangles, Leslie G. The faces of the Gods Vodu and Roman Catholicism in Haiti. North Carolina and London: The University of North Carolina Press, 1992. 
Fausset, Richard. "Santeria Priest Won't Let Religious Freedom be sacrificed," 11 August, 2008, http:// www.latimes.com/news/nationwide/nation/la-na-santerial1-2008.

Fernandez Olmos, Margarite and Paravisini-Gebert, Lizabet. Creole Religions of the Caribbean, and Introduction from Vodou and Santeria to Obeah and Espirtismo. New York and London: New York University, 2003.

Ferrer, Jorge. "Fidel Castro, Coral Gables y Haile Selassie: Charla con Oba Ernesto Pichardo," 8 December, 2008, http://www.cuba encuentro.com.

Florida Statutes, Sec. 828.22 (2008).

Galloway, Joseph. 1780. Historical and Political Reflections on the Rise and Progress of the American Rebellion. London. G. Wilkie.

“Gables City Manger Dined on your Dime," Miami Herald. 26 July, 2008.

Geertz, Clifford. The Interpretation of Cultures. New York: Basic Books, 1973.

Gonzalez-Wippler, Migene. 2007. Santeria: The Real Religion. $2^{\text {nd }}$ Edition. USA. Harmony Books.

Goodnough, Abby. "A City Defines Beautiful, but a Truck Owner and a Court Object," Coral Gables Journal. 31 August, 2007.

Hoffman, Matthew Cullinan. "Brazilian Judge: Catholic Priest's Book Denouncing Witchcraft Must be Removed from Bookstores", LifeSiteNews.com. 7 July, 2008. http://www.lifestitenews.com/ldn/2008/jul/08070710.html.

Icbackerblog.blogspot,http://Icbackerblog.blogspot.com/2008/09/from-cuba-to-united states-santera-and.html.

Johnson, Ed. "Man Admits Dead Animals Part of Santeria Ritual," APP.com. 3 July, 2008 .

Johnson, Paul M. 1999. A History of the American People. USA. Harper Perennial.

Journal of Animal Law, Michigan State University (2006).

Kearney, Michael. 1984. World View. USA. Chandler \& Sharp.

Kramer, Donald T., JD. Constitutional Law, 16A Am. Jur. 2d Constitutional Law $\$ 424$.

(_). Constitutional Law, 16A Am. Jur. 2d Constitutional Law $\$ 429$.

Lazo, Irete. The Accidental Santera. New York: Thomas Dunne Books, 2008.

Livingston, James C. Anatomy of the Sacred and Introduction to Religion, $5^{\text {th }} \mathrm{Ed}$. New Jersey: Pearson \& Prentice Hall, 2005. 
Lupu, Ira C. Lupu. Where Rights Begin: The Problem of Burdens on the Free Exercise of Religion, 102 Harv. L. Rev. 933 (1989).

Lush,Tamara. "Death in the City Beautiful," Miami Newtimes.com. 12-18 July 2008.

Mason, Michael Atwood. Living Santeria: Rituals and Experiences in Afro-Cuban Religion. Washington and London. Smithsonian Institution Press, 2002.

Mason, Michael Atwood, e-mail message to author, November 26, 2007.

Mbiti, John S. African Religions and Philosophy, 2nd Edition. USA: Heinemann, 1992.

Mbiti, John S. Introduction to African Religion, $2^{\text {nd }}$ Ed. Great Britain: Heinemann, 1991.

McConnell, Michael W. The Origins and Historical Understanding of Free Exercise of Religion, 103 Harv. L. Rev. 1409 (1990).

( ${ }^{-}$. The Origins and Historical Understanding of Free Exercise of Religion, 103 Harv. L. Rev. 1409 (1990).

Menniger, Karl A.. II, J.D., Interference with the Right to Free Exercise of Religion, 63 A. Jury. POF 3d 195.

Moretta, John. 2006. William Penn and the Quaker Legacy. USA. Longman.

Mubimde, V.Y. The Invention of Africa: Gnosis, Philosophy and the Order of Knowledge (African Systems of Thought). USA: Indiana University Press, 1988.

Nodal, Roberto and Miguel "Willie" Ramos. 2005. Let the Power Flow: Ebó as a Healing Mechanism in Lukumí Orisha Worship, in Fragments of Bone Neo African Religions in a New World. USA. University of Illionis Press.

Norman, Bob. "Desperate Times," The Daily Pulp, New Times. 12 June, 2008. http://blogs.browardpalmbeach.cm/pulp/2008/06/desperate times.php

O'Brien, David. Animal Sacrifice and Religious Freedom: Church of the Lukumi Babalu Aye v. City of Hialeah. USA: University Press of Kansas, 2004.

Olupona, Jacob K. African Traditional Religions in Contemporary Society. (Chapter 11 only). Minnesota: Paragon House Publishers, 1998.

Opoku, Asare Kofi. West Africa Traditional Religion. Singapore: FEP International Private Limited, 1978. 
Passeggio, Alyssa. "What Washed up on the Keansburg Beach," The Courier. 8 May, 2008.

"Police Urged to Exercise Tolerance Over Sacrifices," CBS-4, 28, July, 2008.

The Public Health and Welfare Act, U.S. Code. Vol. 42, Sec. 2000cc.

Ramos, Willie. video, 1993

Ray, Benjamin C. African Religions Symbol, Ritual and Community, $2^{\text {nd }}$ Edition, USA: Prentice Hall, Inc, 2000.

Religious Freedom Restoration Act of 1998. ,42 U.S.C. § 2000bb, Secs. 760-765.

Roth, Daniel Shoer. "Boring' Ranking Misses Soul of Hialeah," Miami Herald. 22 January, 2009.

Sanchez, Verna C. Essay: Looking Upward and Inward: Religion and Critical Theory, 19 Chicano-Latino L. Rev. 431 (1998).

Sandoval, Mercedes Cros. Worldview, the Orichas, and Santeria: Africa to Cuba and Beyond. Florida: University Press of Florida, 2007.

"Santeria Priest's Suit Highlights religious, cultural Clashes," Associated Press. 24 March, 2007.

"Separated by Religion, United....," Southfloridasuntimes.com. 1 May, 2008.

Schaaf, Gregory. 2004. Franklin, Jefferson and Madison: on Religion and the State. Center for Indigenous Arts \& Cultures.

(_. "Secrecy Espouses Lies," CGGazette.com, 12 June, 2008.

Shay, Miya. "Advocates for Hispanics Blast Valero Plant, "ABC-13 Eyewitness News, and 19 August, 2008.

Smart, Ninian. The Religious Experience. New Jersey: Prentice Hall, Inc. 1996.

Smith, Huston. Why Religion Matters. New York: Harper Collins Books, 2001. This is Barrios-The Changing Face of America. Documentary. Produced by Globe Link Production.

Tomaso, Bruce, "New Miami Police Handbook Includes Tips on Dealing with Animal Sacrifice, 5, August, 2008, http://religionblog.dallasnews.com/archives/2008/08/newmiami-police-handbook-incl.html.

U.S. Census Bureau, State and County Quick Facts Hialeah (city), Florida, http://quickfacts.census.gov/qfd/states/12/1230000.html. 
U.S. Census Bureau, State and County Quick Facts Coral Gables (city), Florida, http://quickfacts.census.gov/qfd/states/12/1214250.html.

Vasquez, Michael, "Santeria Figure Says he may Enter Politics," Miami Herald.com. 22 May, 2003.

Volokh, Eugene. "Unconstitutional Los Angeles Ban on Ritual Animal Sacrifice, "The Volokh Conspiracy, 6 October, 2008, http://Volokh.com/post/1223337499.shtmll.

Volsky, George. "P-card Scandal Draws Region's Interest," CGGazette.com. 20 May, 2005.

( ${ }^{2}$. The World's Religion's. $2^{\text {nd }}$ Ed. United Kingdom: Cambridge University Press, 2006. 